\title{
Acute toxicity, brine shrimp cytotoxicity and relaxant activity of fruits of callistemon citrinus curtis
}

Niaz Ali ${ }^{1,2^{*}+}$, Ghayour Ahmed², Syed Wadood Ali Shah², Ismail Shah², Mehreen Ghias ${ }^{2}$ and Imran Khan ${ }^{3}$

\begin{abstract}
Background: Callistemon citrinus Curtis belongs to family Myrtaceae that has a great medicinal importance. In our previous work, fruits of Callistemon citrinus were reported to have relaxant (antispasmodic) activity. The current work describes the screening of fractions of the crude methanol extract for tracing spasmolytic constituents so that it shall help us for isolation of bioactive compounds. Acute toxicity and brine shrimp cytotoxicity of crude methanol extract are also performed to standardize it.

Methods: The crude methanol extract was obtained by maceration with distilled water $(500 \mathrm{ml})$ three times and fractionated successively with $n$-hexane, chloroform, ethyl acetate and $n$-butanol (300 $\mathrm{ml}$ of each solvent). Phytochemical analysis for crude methanol extract was performed. Acute toxicity studies were performed in mice. Brine shrimp cytotoxicity studies were performed to determine its cytotoxicity and standardize it. In other series of experiments, rabbits' jejunum preparations were used in screening for possible relaxant activities of various fractions. They were applied in concentrations of $0.01,0.03,0.1,0.3,1.0,3.0,5.0$ and $10.0 \mathrm{mg} / \mathrm{ml}$ on spontaneous rabbits' jejunum preparations. In similar fashion, fractions were also tested on $\mathrm{KCl}(80 \mathrm{mM})$-induced contractions. Calcium chloride curves were constructed in K-rich Tyrode's solution. The effects of various fractions were tested on calcium chloride curves at concentrations 1.0, 3.0, 5.0 and $10.0 \mathrm{mg} / \mathrm{ml}$. Curves of verapamil used as reference drug at concentration $0.1 \mu \mathrm{M}$ and $0.3 \mu \mathrm{M}$ were also constructed. The curves were compared with their respective controls for possible right shift.
\end{abstract}

Results: Methanol extract tested strongly positive for saponins and tannins. However, it tested mild positive for presence of proteins, amino acids, carbohydrates and phenolic compounds. $L D_{50}$ value for crude methanol extract is $476.25 \pm 10.3(470-481, \mathrm{n}=4) \mathrm{mg} / \mathrm{ml}$. Similarly, $\mathrm{EC}_{50}$ value for brine shrimp cytotoxicity is $65.5 \pm 7.28(60.8-69.4$, $\mathrm{n}=4) \mathrm{mg} / \mathrm{ml}$. All the fractions relaxed the spontaneous and $\mathrm{KCl}$-induced contractions. $\mathrm{EC}_{50}$ values $(\mathrm{mg} / \mathrm{ml})$ for effects of ethyl acetate fraction on spontaneous and $\mathrm{KCl}$ induced contractions are $2.62 \pm 0.78(2.15-3.0, \mathrm{n}=4)$ and $3.72 \pm 0.86(3.38-4.28, \mathrm{n}=4)$ respectively. Respective $E C_{50}$ values $(\mathrm{mg} / \mathrm{ml})$ for $n$-butanol fraction are $3.59 \pm 0.2(3.07$ $3.9, \mathrm{n}=4)$ for spontaneous, and $5.57 \pm 0.2(5.07-6.11, \mathrm{n}=4)$ for $\mathrm{KCl}$ - induced contractions. $\mathrm{EC}_{50}$ value for control calcium chloride curve (without extract) is $-2.73 \pm 0.19(-2.6--2.81, \mathrm{n}=4)$ while $\mathrm{EC}_{50}$ for curves treated with 5.0 $\mathrm{mg} / \mathrm{ml}$ of chloroform is $-2.22 \pm 0.02(-2.16--2.3, \mathrm{n}=4)$. $\mathrm{EC}_{50}$ value for ethyl acetate treated $(1.0 \mathrm{mg} / \mathrm{ml})$ tissues is $-1.95 \pm 0.10(-1.88--2.0, \mathrm{n}=4)$ vs. control $\mathrm{EC}_{50}=-2.71 \pm 0.08(-2.66--2.76, \mathrm{n}=4)$. All the fractions, except $n-$ hexane, showed a right shift like that of verapamil $\left(\mathrm{EC}_{50}=-1.72 \pm 0.15(-1.62--1.8, \mathrm{n}=4)\right.$ vs. Control $\mathrm{EC}_{50}=-2.41$ $\pm 0.06(-2.38--2.44, n=4)$, a standard drug that blocks voltage operated calcium channels.

Conclusion: Relaxant constituents were more concentrated in ethylacetate fraction followed by chloroform, $n$ -butanol and aqueous fractions that warrant for its isolation. The crude methanol extract is safe at concentration

\footnotetext{
* Correspondence: niazpharmacist@yahoo.com

+ Contributed equally

'Department of Pharmacology, Institute of Basic Medical Sciences, Khyber

Medical University, Peshawar, KPK, Pakistan

Full list of author information is available at the end of the article
} 


\section{Background}

Family Myrtaceae consists of 3800 species, which are distributed in 140 genera. The plants are mostly found in tropical and subtropical regions of the world [1].The genus Callistemon belongs to family Myrtaceae. The plants of this genus are small evergreen beautiful trees and shrubs, which contain approximately 34 species. The cylindrical brush like flowers resemble traditional bottle brush, hence, the plant is commonly named as bottle brush [2].The leaves of Callistemon species are aromatic and lanceolate, mostly 40-70 mm long and 3-6 $\mathrm{mm}$ wide. The flowers are borne in spikes of about 40$150 \mathrm{~mm}$ long with prominent red stamens while its petals are tiny, pale or greenish colored [3]. Mostly, the species of this genus are used for ornamental purpose. However, species of the genus are sources of insecticidal, antibacterial and antifungal bioactive compounds as well [4]. Beside these activities, the genera have also some additional medicinal properties like antithrombotic, repellent, nematocidal, larvicidal and pupicidal activities [5]. Traditionally, in Chinese medicine, Callistemon viminalis is used for the treatment of hemorrhoids [6]. Callistemon species are also used for weed control, as bio indicators for environmental management, and a source of essential oil production as well. Phytochemically, the essential oils of Callistemon citrinus and $C$. viminalis contain $\alpha$-pinene, $\beta$-pinene, $\alpha$-terpinene, 1,8 cineole, linalool, trans-pinocarveol, terpinen-4-ol, geraniol and $\alpha$-terpineol that has showed antibacterial activity [3,7]. Preliminary screening of Callistemon linearis has revealed the presence of glycosides, saponins, flavonoids, phenolic compounds, phytosterols and carbohydrates. Hydro distillation of volatile oils mainly contain $n$-De-3-ene, 3-carene, 1, 8-cineole, $\gamma$-terpinene [2]. The Stem bark of Callistemon rigidus has led to the isolation of scirpusin B and piceatannol that have inhibitory activity on mouse alpha amylase [6]. In our first attempt for pharmacological screening of fruits of Callistemon citrinus, we have reported relaxant activity of its crude methanol extract on rabbits' jejunum preparations with possible mechanism through voltage operated calcium channels [8]. Objective of our current work is to screen the various fractions of crude methanol extract of Callistemon citrinus, and to know fraction(s) in which are concentrated the relaxant constituents. So that it shall make other scientists convenient for activity guided isolation of bioactive compounds. Acute toxicity and cytotoxic activities have also been performed to standardize the crude methanol extract of $C$. citrinus fruits.

\section{Methods}

Collection, extraction and fractionation of plant materials Fresh fruits of Callistemon citrinus were collected in July 2009 from the campus of University of Malakand, KPK, Pakistan. The fruits were subjected to shade drying. The plant voucher specimen (CC-01-2009) was identified by Professor Dr. Jehandar Shah, vice chancellor Shaheed Benazir Bhutto University, Sheringal Dir Upper, Sheringal. The fruits were grinded to fine powder. The powdered materials $(4.0 \mathrm{Kg})$ were soaked in commercial grade methanol (6 Liters) for 4 days. The materials were filtered through ordinary filter paper. The process was repeated thrice. The filtrates were combined and concentrated, at $40^{\circ} \mathrm{C}$ under reduced pressure, using a rotary evaporator till a brownish crude extract (400.0 g) was obtained. The brownish extract $(350.0 \mathrm{~g})$ was dissolved in $500 \mathrm{ml}$ distilled water and was successively fractionated with $(300 \mathrm{ml}$ of each solvent, three times each) $n$-hexane, chloroform, ethyl acetate and $n$-butanol. Each fraction was treated as described above yielding corresponding fractions upon evaporation as $n$-hexane (30.0 g), chloroform (70.0 g), ethyl acetate (120.0 g), nbutanol $(60.0 \mathrm{~g})$ and residual aqueous fraction $(70.0 \mathrm{~g})$.

\section{Drugs and animals}

All solutions were prepared on same day of experiments. Analytical grade chemicals were used in the experiments. Acetylcholine was purchased from BDH chemicals, Poole, England. Rests of the chemicals were purchased from E Merck Germany. Rabbits of either sex (weighing 1.4-2.0 Kg) were used in experiments $(\mathrm{n}=4$ each) as per "Byelaws of the University of Malakand 2008, Scientific Procedures, Issue I". The animals had a free access to water. However, they were starved 24 hours prior to start of experiments. Ethical Committee of Department of Pharmacy, University of Malakand approved the study protocols.

\section{Data recordings}

Intestinal responses were recorded with help of a Force Transducer (Model No: MLT 0210/A Pan Lab S.I.), connected with Power lab (Model No: 4/25 T) AD Instruments, Australia. Bridge Pod Amplifier was used for amplification of responses. Setting parameters were at range of $20 \mathrm{mv}$, Low pass $5 \mathrm{~Hz} \times 10$ gain using input 1 , rate $40 / \mathrm{S}$.

\section{Statistical analysis and interpretation of data}

Statistical analysis was performed at $95 \%$ confidence interval. P value equal to or less than 0.05 was considered as significant. Chart 5 supplied with the power Lab 
was used to interpret the data. Microsoft XL sheet was used to calculate mean values. Graph Pad prism was used to calculate mean, SEM and draw the curves for $\mathrm{LD}_{50}, \mathrm{EC}_{50}$ shift.

\section{Preliminary phytochemical screenings}

Preliminary phytochemical screenings were performed for presence of saponins, tannins, carbohydrates, steroids, proteins, amino acids, phenolic compounds and anthraquinone glycosides $[9,10]$.

\section{Acute toxicity studies}

Acute toxicity study on crude methanol extract was performed using mice model. Lorke (1983) method was used for acute toxicity study. The crude methanol extract was administered intraperitoneally (i.p) in mice [11]. Mice of either sex were fasted overnight. In the first stage of the preliminary screening, 3 groups, each of 3 mice were treated with the crude methanol extract at doses of 10,100 and $1000 \mathrm{mg} / \mathrm{kg}$ (i.p) for the determination of the lethal range. In the second stage, another 4 groups of 3 mice each were further treated with the extract at doses of 125, 250, 400 and $600 \mathrm{mg} /$ $\mathrm{kg}$. Animals were continuously observed for 24 hours, after dosing, for study of acute toxicity. In each group, numbers of deaths were recorded within 24 hours. $\mathrm{LD}_{50}$ values were calculated.

\section{Brine shrimp cytotoxicity study}

Brine shrimp lethality bioassay was performed to investigate the cytotoxicity of crude methanol extract of Callistemon citrinus. Brine shrimp (Artemia salina) eggs were hatched using a conical shaped vessel (capacity $=$ $1 \mathrm{~L}$ ) containing sterile artificial seawater (sea salt $38.0 \mathrm{~g} /$ $\mathrm{L}$; adjusted $\mathrm{pH}$ 8.5) [12]. They were kept for 48 hours with continuous aeration. After hatching, active nauplii free from egg shells, were collected from brighter portion of the hatching chamber. Dimethyl sulfoxide (DMSO, $1.0 \mathrm{ml}$ ) was used for the preparation of different concentrations $(1000,100,10 \mu \mathrm{g} / \mathrm{ml})$ of sample extract, in triplicates. After evaporation of vehicle solvent, each test tube was introduced with ten brine shrimp larvae (10 nauplii). All test tubes were maintained at room temperature for 24 hours. The numbers of surviving and dead shrimps were counted. Percentage mortality was determined. Each concentration was triplicated. $\mathrm{EC}_{50}$ were calculated using graph pad prism software.

\section{Effects on spontaneous rabbits' jejunum preparations and $\mathrm{KCl}$ - induced contractions}

Rabbits were given a blow on cervix for cervical dislocation. Their abdomens were opened. Pieces of jejunum were removed and placed in Tyrode's solution aerated with carbogen gas $\left(95 \% \mathrm{O}_{2}: 5 \% \mathrm{CO}_{2}\right)$. Constituents and concentrations ( $\mathrm{mM})$ used in Tyrode's solution were $\mathrm{KCl} 2.68, \mathrm{NaCl} 136.9, \mathrm{MgCl}_{2}$ 1.05, $\mathrm{NaHCO}_{3}$ 11.90, $\mathrm{NaH}_{2} \mathrm{PO}_{4}$ 0.42, $\mathrm{CaCl}_{2} 1.8$ and glucose 5.55. The mesentery was removed. Pieces of about 1-1.5 cm length were mounted in $10 \mathrm{ml}$ tissue bath at control temperature $37 \pm 1^{\circ} \mathrm{C}$. After stabilization, various fractions $(n-$ hexane, chloroform, ethyl acetate, $n$-butanol and aqueous) of crude methanol extract were tried at concentrations $0.01,0.03,0.1,0.3,1.0,3.0,5.0$ and $10.0 \mathrm{mg} / \mathrm{ml}$ [13-16]. Effects were recorded. Sustained contractions were produced in rabbits' jejunum preparations by $\mathrm{KCl}$ $(80 \mathrm{mM})$. The fractions were tried in similar concentrations. Its effects were noted.

\section{Effects on calcium chloride curves in decalcified tissues}

In order to explain the possible mode of action, the tissues were successively decalcified in K-Normal Tyrode's solution and K Rich Tyrode's solution [13-16]. Earlier, the tissues were stabilized in normal Tyrode's solution for about 20 minutes. The composition of normal Tyrode's solution $(\mathrm{mM})$ was $\mathrm{KCl} 2.68, \mathrm{NaCl} 136.9, \mathrm{MgCl}_{2}$ $1.05, \mathrm{NaHCO}_{3} 11.90, \mathrm{NaH}_{2} \mathrm{PO}_{4} 0.42, \mathrm{CaCl}_{2} 1.8$ and glucose 5.55. Constituents and concentration $(\mathrm{mM})$ of $\mathrm{K}$ Rich Tyrode's solution was $\mathrm{KCl} 50, \mathrm{NaCl} 91.04, \mathrm{MgCl}_{2}$ 1.05, $\mathrm{NaHCO}_{3} 11.90, \mathrm{NaH}_{2} \mathrm{PO}_{4} 0.42$, glucose 5.55 and EDTA 0.1. Control (in absence of test fractions) calcium chloride curves were constructed in decalcified tissues. The tissues were then exposed to known concentrations of fractions. An incubation period of 1 hour was given to same tissues so that test extract could produce possible calcium channel blocking effects. Calcium chloride curves were reconstructed to observe the effects of test extract. $\mathrm{EC}_{50}$, in the presence of extract, were calculated and compared with $\mathrm{EC}_{50}$ of control curves (absence of extract). In other series of experiments, in similar manners, curves were constructed for calcium chloride in presence and absence of known concentrations of verapamil. $\mathrm{EC}_{50}$ were calculated and compared with control curves for possible right shift. Curves of the fractions were compared with curves of verapamil, a standard calcium channel blocker for voltage operated calcium channels.

\section{Results and discussion}

Upon preliminary phytochemical screenings, methanol extract tested strongly positive for saponins and tannins. However, it tested positive for presence of proteins, amino acids, carbohydrates and phenolic compounds (Table 1). Further, it tested negative for presence of steroids, alkaloids, flavonoids and anthraquinone glycosides. In our earlier published report, the crude extract has tested positive for presence of terpenes (terpenoids) and saponins glycosides [8-10]. Results of acute toxicity studies are summarized in Table 2. In the initial stage of screening, all animals of group 3 died showing that the methanol extract is $100 \%$ lethal at the said concentration $1000 \mathrm{mg} / \mathrm{kg}$. At dose $10 \mathrm{mg} / \mathrm{kg}$ (group 1) and $100 \mathrm{mg} / \mathrm{kg}$ (group 2), all animals survived. In the $2^{\text {nd }}$ 
Table 1 Phytochemical screening of crude methanol extract of Callistemon citrinus.

\begin{tabular}{cll}
\hline S. No & Class of Phytochemicals & Results \\
\hline 1 & Saponins & +++ \\
2 & Tannins & +++ \\
3 & Carbohydrates & + \\
4 & Steroids & - \\
5 & Proteins & + \\
6 & Amino Acids & + \\
7 & Phenolic Compounds & + \\
8 & Flavonoids & - \\
9 & Anthraquinone glycosides & - \\
10 & Alkaloids & -
\end{tabular}

phase of screening, animals of group 1 and group 2 survived, respectively at concentration $125 \mathrm{mg} / \mathrm{kg}$ and 250 $\mathrm{mg} / \mathrm{kg}$ of crude methanol extract, while one mouse died at concentration of $400 \mathrm{mg}$. All animals in group 4 died. Their \% lethality is expressed in Figure $1 . \mathrm{LD}_{50}$ value for the graph in Figure 1 is $476.25 \pm 10.3$ (470$481, \mathrm{n}=4) \mathrm{mg} / \mathrm{ml}$. Similarly, results of brine shrimp cytotoxicity studies are expressed in Figure 2. EC $\mathrm{E}_{50}$ value is $65.5 \pm 7.28(60.8-69.4, \mathrm{n}=4) \mathrm{mg} / \mathrm{ml}$. It is, thus stated that the plant specie has good cytotoxic effect and, therefore, may be a source of anticancer constituents as there is positive correlation between the brine shrimp toxicity and human nasopharyngeal carcinoma [12]. Thus the brine shrimp cytotoxicity implies for presence of cytotoxic constituents as well. As per our previous reported work [8] that crude methanol extract possess relaxant activity on rabbits' jejunum preparations, the current work describes the screening of fractions of Callistemon citrinus for possible relaxant effects that may be helpful for other scientists for further work. According to Figure 3(A), which describes the results for effects of chloroform fraction, the $\mathrm{EC}_{50}$ value on spontaneous rabbits' jejunum preparations is $7.84 \pm 0.16(7.42-8.18, \mathrm{n}=4) \mathrm{mg} / \mathrm{ml}$ while $\mathrm{EC}_{50}$ for $\mathrm{KCl}$ -induced contractions at $7.0 \pm 0.73(6.63-7.42, \mathrm{n}=4)$ $\mathrm{mg} / \mathrm{ml} . \mathrm{EC}_{50}$ values $(\mathrm{mg} / \mathrm{ml})$ for effects of ethyl acetate fraction on spontaneous and $\mathrm{KCl}$ induced contractions

Table 2 Results of acute toxicity studies of crude methanol extract of Callistemon citrinus in mice.

\begin{tabular}{|c|c|c|c|c|}
\hline \multirow[t]{2}{*}{$1^{\text {st }}$ stage } & \multicolumn{3}{|c|}{$\begin{array}{c}\text { Dose } \\
\text { (mg/kg Body weight) }\end{array}$} & \\
\hline & $\begin{array}{l}\text { Group } 1 \\
(10 \mathrm{mg})\end{array}$ & $\begin{array}{l}\text { Group } 2 \\
(100 \mathrm{mg})\end{array}$ & $\begin{array}{l}\text { Group } 3 \\
(1000 \mathrm{mg})\end{array}$ & \\
\hline \multirow{3}{*}{$2^{\text {nd }}$ stage } & All alive & All alive & All dead & \\
\hline & $\begin{array}{l}\text { Group } 1 \\
(125 \mathrm{mg})\end{array}$ & $\begin{array}{l}\text { Group } 2 \\
(250 \mathrm{mg})\end{array}$ & $\begin{array}{l}\text { Group3 } \\
(400 \mathrm{mg})\end{array}$ & $\begin{array}{l}\text { Group } 4 \\
(600 \mathrm{mg})\end{array}$ \\
\hline & All alive & All alive & 1 died & All dead \\
\hline
\end{tabular}

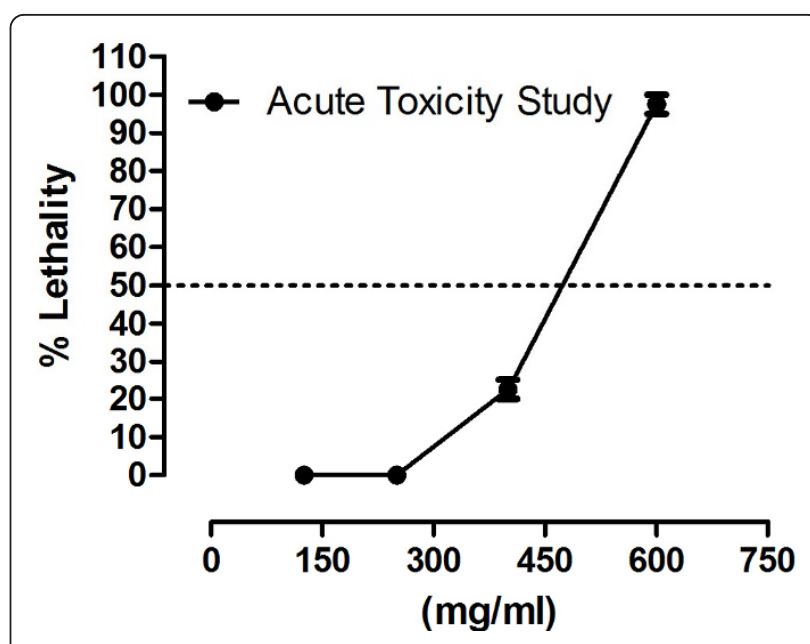

Figure 1 Results of crude methanol extract of fruits of Callistemon citrinus for acute toxicity study in mice.

are $2.62 \pm 0.78(2.15-3.0, \mathrm{n}=4)$ and $3.72 \pm 0.86(3.38$ $4.28, \mathrm{n}=4$ ) respectively (Figure $3(\mathrm{~B})$ ). Respective $\mathrm{EC}_{50}$ values for $n$-butanol fraction are $3.59 \pm 0.2$ (3.07-3.9, $n$ $=4)$ and $5.57 \pm 0.2(5.07-6.11, \mathrm{n}=4) \mathrm{mg} / \mathrm{ml}$ (Figure 3 (C)). Similarly, respective $\mathrm{EC}_{50}$ values for aqueous fraction are $7.99 \pm 0.3(7.07-8.73, \mathrm{n}=4)$ and $9.62 \pm 0.1$ $(9.47-9.79, \mathrm{n}=4) \mathrm{mg} / \mathrm{ml}$ (Figure 3(D)). $\mathrm{EC}_{50}$ values for $n$-hexane fraction were not calculated as its effects on spontaneous and $\mathrm{KCl}$-induced contractions were very low. This fraction could not relax more than $15 \%$ of control response (Figure 3(E)). The contractile effects of the jejunum are due to free calcium levels of the tissues. The intracellular and extracellular calcium stores also exchange with each other that lead to periodic depolarization and repolarization of jejunum. The periodic depolarization and repolarization are responsible for the intestinal responses [13-15,17-21]. It is not necessary that relaxing effects on $\mathrm{KCl}$ induced contractions are

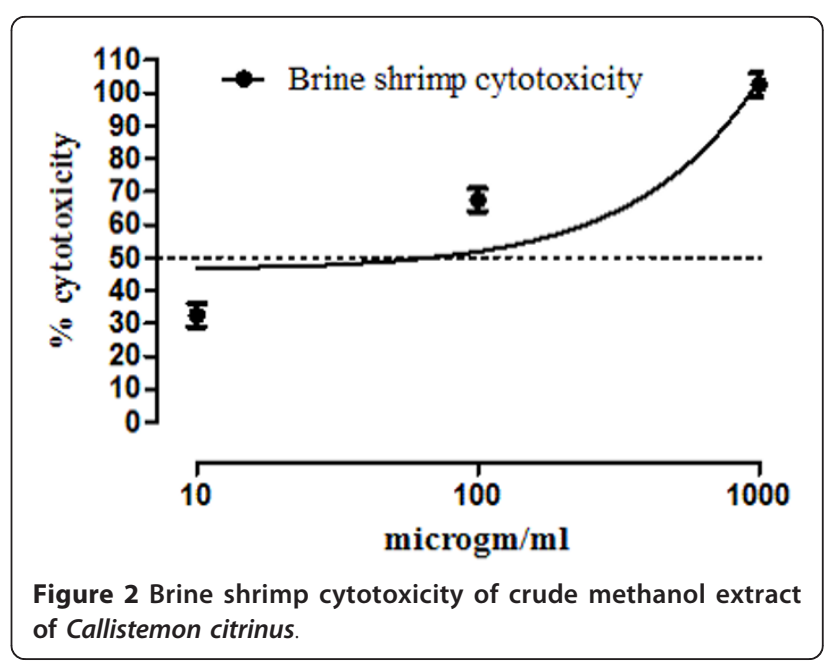



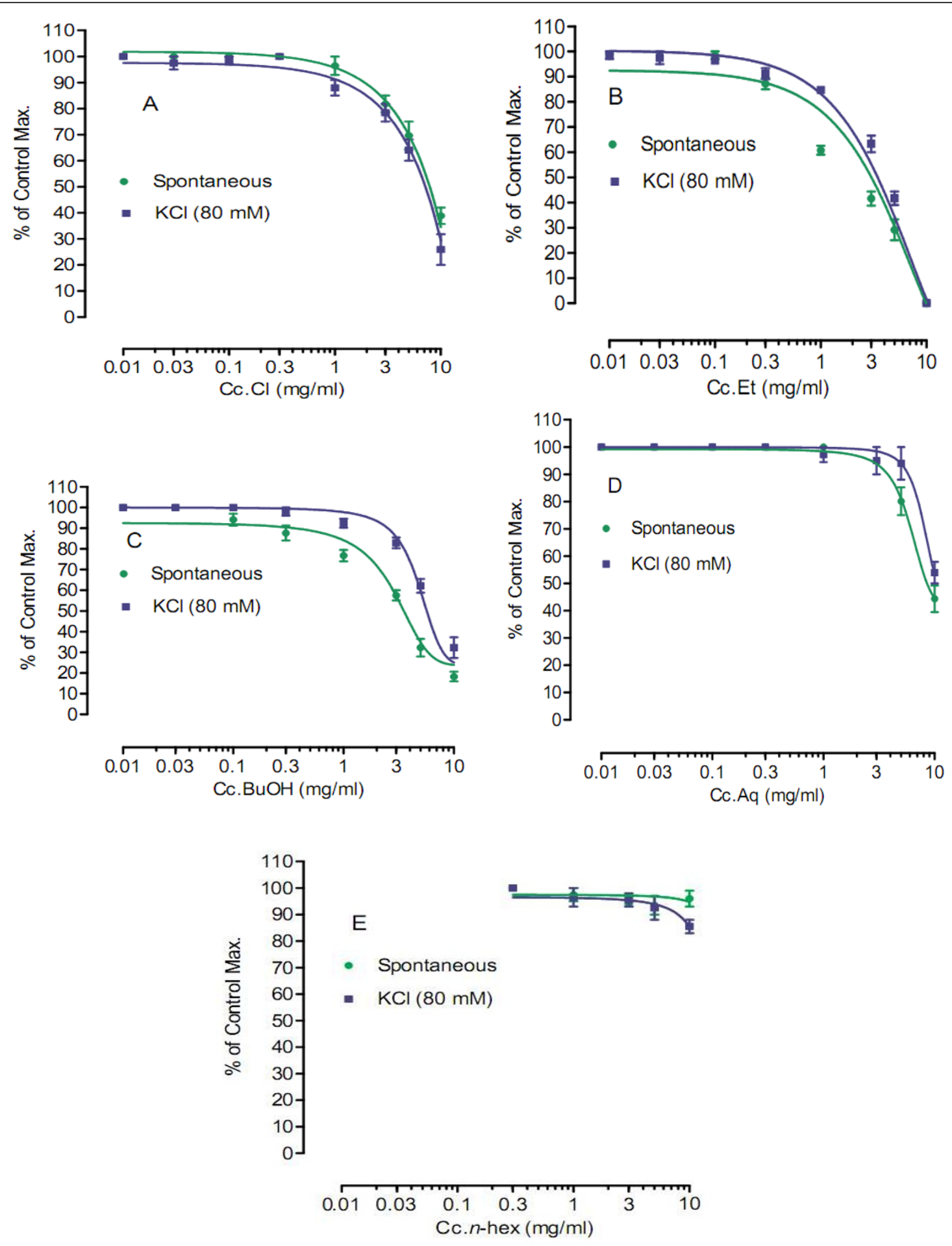

Figure 3 (A): Effects of Chloroform fraction of Callistemon citrinus (Cc.Cl) on spontaneous and $\mathrm{KCl}$-induced contractions. (B): Effects of ethyl acetate fraction of Callistemon citrinus (Cc.Et) on spontaneous and KCl-induced contractions. (C): Effects of $n$-butanol fraction of Callistemon citrinus (Cc.BUOH) on spontaneous and $\mathrm{KCl}$-induced contractions. (D): Effects of aqueous fraction of Callistemon citrinus (Cc.Aq) on spontaneous and $\mathrm{KCl}$-induced contractions. (E): Effects of $n$-hexane fraction of Callistemon citrinus (Cc.n-hex) on spontaneous and KCl-induced contractions. 

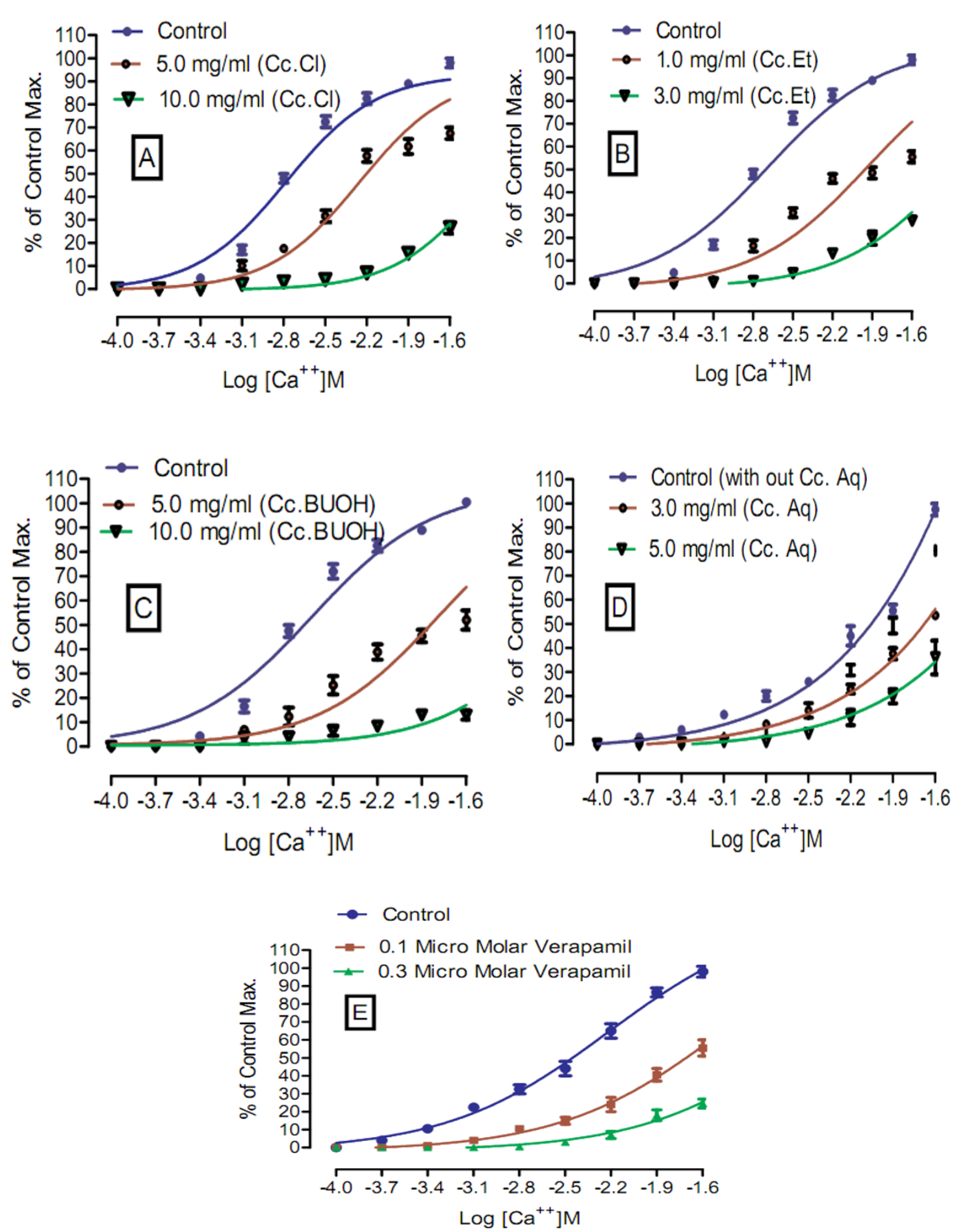

Figure 4 (A): Effects of chloroform fraction of Callistemon citrinus (Cc.Cl) on calcium chloride curves versus control. (B): Effects of ethylacetate fraction of Callistemon citrinus (Cc.Et) on calcium chloride curves versus control. (C): Effects of $n$-butanol fraction of Callistemon citrinus ( $\mathrm{Cc} . \mathrm{B} \cup \mathrm{OH}$ ) on calcium chloride curves versus control. (D): Effects of aqueous fraction of Callistemon citrinus (Cc.Aq) on calcium chloride curves versus control. (E): Effects of O.1 $\mu \mathrm{M}$ Verapamil on calcium chloride curves versus control. 
always through calcium channels $[13,14]$; hence, the calcium chloride curves in decalcified tissues were constructed (Figure 4) [13-17]. Figure 4 (A) shows the effects of chloroform fraction on calcium chloride curves, $\mathrm{EC}_{50}\left[\log \left(\mathrm{Ca}^{++}\right) \mathrm{M}\right]$ value for control curve (without extract) is $-2.73 \pm 0.19(-2.6--2.81, \mathrm{n}=4$ ) while $\mathrm{EC}_{50}$ for curves treated with $5.0 \mathrm{mg} / \mathrm{ml}$ of chloroform is $-2.22 \pm 0.02(-2.16--2.3, \mathrm{n}=4)$. $\mathrm{EC}_{50}$ value for ethylacetate treated $(1.0 \mathrm{mg} / \mathrm{ml})$ tissues is $-1.95 \pm 0.10$ $(-1.88--2.0, \mathrm{n}=4)$ vs. control $\mathrm{EC}_{50}=-2.71 \pm 0.08$ $(-2.66-2.76, n=4)$ (Figure $4(B))$. Similarly, for $n$ butanol fraction, $\mathrm{EC}_{50}$ values for control and $5 \mathrm{mg} / \mathrm{ml}$ of the fraction are, respectively, $-2.71 \pm 0.10(-2.65-$ $-2.77, \mathrm{n}=4)$ and $-1.82 \pm 0.07(-1.79--1.87, \mathrm{n}=4)$ (Figure $4(\mathrm{C})$ ). In case of aqueous fraction, $\mathrm{EC}_{50}$ for control $=-2.09 \pm 0.10(-2.04--2.15, \mathrm{n}=4)$ (Figure $4(\mathrm{D})$ ), while $\mathrm{EC}_{50}$ value for aqueous fraction $(3 \mathrm{mg} / \mathrm{ml})=-1.66$ $\pm 0.10(-1.6--1.72, \mathrm{n}=4)$ (Figure $4(\mathrm{D})) . \mathrm{EC}_{50}$ value for verapamil $(0.1 \mu \mathrm{M})$ treated tissues $=-1.72 \pm 0.15$ $(-1.62--1.8, \mathrm{n}=4)$ vs. Control $\mathrm{EC}_{50}=-2.41 \pm 0.06$ $(-2.38--2.44, \mathrm{n}=4)$ (Figure $4(\mathrm{E}))$. Thus all the fractions, except $n$-hexane, showed a right shift like that of verapamil, a standard drug that blocks voltage operated calcium channels. This suggests the presence of calcium antagonist compounds in the fractions of the crude methanol extract. It is noteworthy (according to our previous published data) that the crude methanol extract of the plant had shifted the calcium chloride curves to right at "concentration of $0.03 \mathrm{mg} / \mathrm{ml}$ of extract treated tissues $\left(\mathrm{EC}_{50}=-2.05 \pm 0.05\left(\mathrm{Log}\left[\mathrm{Ca}^{++}\right]\right.\right.$ $\mathrm{M}$ vs. control $\mathrm{EC}_{50}=-2.5 \pm 0.05\left(\mathrm{Log}\left[\mathrm{Ca}^{++}\right] \mathrm{M}\right) "$ [8]. The current study on fractions of the crude methanol extract revealed that the calcium antagonist compounds were concentrated more in ethylacetate fraction that produced right shifted at $1 \mathrm{mg} / \mathrm{ml}$, followed by aqueous fraction where it produced right shift at concentration $3.0 \mathrm{mg} / \mathrm{ml}$. $n$-butanol and chloroform fractions showed a right shift at $5.0 \mathrm{mg} / \mathrm{ml}$. It is thus concluded that the presence of calcium antagonists were more concentrated in ethylacetate fraction that opens a new window for phytochemists for isolation of bioactive calcium antagonists directly from the ethyl acetate fraction. The relaxant effect of fractions of Callistemon citrinus on rabbit's jejunum preparations may be attributed to the phytochemical constituents such as saponins, tannins and triterpenes present in the plant as also reported in previous studies [15,22-24]. The cytotoxic activity may be attributed to saponins as well [24].

\section{Conclusions}

Relaxant constituents were more concentrated in ethylacetate fraction followed by chloroform, $n$-butanol and aqueous fractions that warrant for its isolation. The crude methanol extract is safe at concentrations 250 $\mathrm{mg} / \mathrm{ml}$ or below and results of brine shrimp cytotoxicity assay imply that the plant specie may be a source of cytotoxic agents.

\section{Acknowledgements}

The authors want to thank Professor Dr. Jehandar Shah, plant taxonomist, vice chancellor Shaheed Benazir Bhutto University, Shiringal, for his unwavering support in identification and supply of this medicinal plant. Funding source: It is a self-funded project.

\section{Author details}

${ }^{1}$ Department of Pharmacology, Institute of Basic Medical Sciences, Khyber Medical University, Peshawar, KPK, Pakistan. ${ }^{2}$ Department of Pharmacy, University of Malakand, Chakdara, Dir, KPK, Pakistan. ${ }^{3}$ Department of Biotechnology, University of Malakand, Chakdara, Dir, KPK, Pakistan.

\section{Authors' contributions}

NA: Data interpretation, preparation of the manuscript, answering the queries of the reviewers and formatting the final manuscript. GA: Data acquisition. SWAS: Data acquisition and helped in writing introduction section of the manuscript. IS:Data acquisition. MG: Data acquisition. IK: Data acquisition. All the authors have read and approved the final proof of the manuscript.

\section{Competing interests}

The authors declare that they have no competing interests.

Received: 6 July 2011 Accepted: 24 October 2011

Published: 24 October 2011

\section{References}

1. Mabberly DJ: The Plant Book. A Portable Dictionary of the Vascular Plants. Cambridge University Press: Cambridge; 21997.

2. Anudwipa D, Zaman K, Akhilesh VS: Phytochemical and chemical composition evaluation of Volatile Oil of Callistemon linearis DC Leaf. Adv Nat App/ Sci 2009, 3(Suppl 1):56-59.

3. Oyedeji OO, Lawal OA, Shode FO, Oyedeji AO: Chemical Composition and Antibacterial Activity of the Essential Oils of Callistemon citrinus and Callistemon viminalis from South Africa. Molecules 2009, 14:1990-1998.

4. Silva CJ, Barbosa LCA, Demuner AJ, Montanari RM, Pinheiro AL, Andrade NJ: Chemical composition and antibacterial activities from the essential oils of Myrtaceae species planted in Brazil. Quim Nova 2010, 33(Suppl1):104-108.

5. Adonizio A L, Downum K, Bennett BC, Mathee K: Anti-quorum sensing activity of medicinal plants in southern Florida. J Ethnopharmacol 2006, 105:427-435.

6. Islam MR, Ahamed R, Rahman MO, Akbar MA, Al-Amin M, Alam KD, Lyzu F: In Vitro Antimicrobial Activities of Four Medicinally Important Plants in Bangladesh. Eur J Sci Res 2010, 39(Suppl 2):199-206.

7. Riaz M, Chaudhary FM: The chemical composition of Pakistani Callistemon citrinus oils. J Ess Oil Res 1990, 2(Suppl 6):327-328.

8. Ali N, Shah SWA, Ahmad B: Calcium channel blocking activity of fruits of Callistemon citrinus. J Chem Soc Pak 2011, 33(Suppl 2):245-248.

9. Trease GE, Evans WC: Text book of Pharmacognosy. Bailliere Tindall, London; 13 1989, 683.

10. Sofowora A: Medicinal Plants and Traditional Medicine in Africa. Spectrum Books Limited, Ibadan, Nigeria; 21993.

11. Akuodor GC, Usman MI, Ibrahim JA, Chilaka KC, Akpan JL, Dzarma S, Muazzam I, Osunkwo UA: Anti-nociceptive, anti-inflammatory and antipyretic effects of the methanolic extract of Bombax buonopozense leaves in rats and mice. Afr J Biotechnol 2011, 10(Suppl 16):3191-3196.

12. Rehman AU, Mannan A, Inayatullah S, Akhtar MZ, Qayyum M, Mirza B: Biological evaluation of wild thyme (Tymus serpyllum). Pharm Biol 2009, 47(Suppl 8):628-633.

13. Gilani AH, Bukhari IA, Khan RA, Arif-ullah K, Farman U, Viqar UA: Cholinomimetic and calcium channel blocking activities of Carthamus oxycantha. Phytother Res 2005, , 19: 679-683.

14. Niaz A, Shah SWA: Spasmolytic Activity of Fruits of Tamarindus indica L. $J$ Y Pharm 2010, 2(Suppl 3):261-264. 
15. Niaz A, Shah SWA: Antispasmodic activity of Teucrium stocksianum Bioss. Pak J Pharm Sci 2011, 24(Suppl 2):171-174.

16. Shah SWA, Kamil S, Ahmad W, Ali N: Spasmogenic, spasmolytic and antihypertensive activity of Forsskalea tenacissima L. Afr J Pharm Pharmacol 2010, 4(Suppl 6):381-385.

17. Karaki H, Wiess G: Mini-review: Calcium release in smooth muscles. Life Sci 1988, 42(Suppl 2):111-122.

18. Van Rossum JM: Cumulative dose- response curves II. Techniques for the making of dose-response curves in isolated organs and the evaluation of drug parameters. Arch Int Pharmacody Ther 1963, 143:299-330.

19. Bolton TB: Mechanism of action of transmitter and other substances on smooth muscles. Physiol Rev 1979, 59(Suppl 3):606-718.

20. Carl A, Lee HK, Sanders KM: Regulation of ion channels in smooth muscles by calcium. (Invited Review). Am J Physiol 1996, 271:C9-C34

21. Godfraind T, Miller R, Wibo M: Calcium antagonism and calcium entry blockade. Pharmacol Rev 1986, 38:321-416.

22. Cortes AR, Delgadillo AJ, Hurtado M, Dominguez-Ramirez AM, Medina JR, Aoki K: The Antispasmodic Activity of Buddleja scordioides and Buddleja Perfoliata on isolated intestinal preparations. Biol Pharma Bull 2006, 29(Suppl 6):1186-1190.

23. Corea G, Fattorusso E, Lanzotti V, Capasso R, Izzo AA: Antispasmodic saponins from bulbs of red onion, Allium cepa L. var. Tropea. J Agr Food Chemis 2005, 53(Suppl 4):935-940.

24. Lanzotti V: Bioactive Saponins from Allium and Aster plants. Phytochem Rev 2005, 4:95-110.

Pre-publication history

The pre-publication history for this paper can be accessed here: http://www.biomedcentral.com/1472-6882/11/99/prepub

doi:10.1186/1472-6882-11-99

Cite this article as: Ali et al: Acute toxicity, brine shrimp cytotoxicity and relaxant activity of fruits of callistemon citrinus curtis. BMC Complementary and Alternative Medicine 2011 11:99.

\section{Submit your next manuscript to BioMed Central and take full advantage of:}

- Convenient online submission

- Thorough peer review

- No space constraints or color figure charges

- Immediate publication on acceptance

- Inclusion in PubMed, CAS, Scopus and Google Scholar

- Research which is freely available for redistribution

Submit your manuscript at www.biomedcentral.com/submit
C Biomed Central 